\title{
EDUKASI PROGRAM INOVASI DESAIN DAN PENGEMBANGAN PERANGKAT PENGENDALI ALAT PAKAN TERNAK OTOMATIS MENGGUNAKAN TEKNOLOGI INTERNET OF THINGS DI DESA KERTASARI, KECAMATAN RENGASDENGKLOK, KARAWANG, JAWA BARAT
}

\author{
Lela Nurpulaela'), Arnisa Stefanie ${ }^{1}$, Dedi Pahroji ${ }^{2)}$, Susilawati ${ }^{3)}$ \\ ${ }^{1)}$ Teknik Elektro, Fakultas Teknik, Universitas Singaperbangsa Karawang, Kab. Karawang, Jawa Barat, Indonesia \\ ${ }^{2}$ )Hukum Adat, Fakultas Hukum, Universitas Singaperbangsa Karawang, Kab. Karawang, Jawa Barat, Indonesia \\ ${ }^{3)}$ Informatika, Fakultas Informatika, Universitas Singaperbangsa Karawang, Kab. Karawang, Jawa Barat, Indonesia
}

Corresponding author: Arnisa Stefanie

E-mail : arnisa.stefanie@staff.unsika.ac.id

Diterima 17 November 2021, Direvisi 04 Desember 2021, Disetujui 04 Desember 2021

\begin{abstract}
ABSTRAK
Pandemi Covid-19 memiliki dampak yang sangat signifikan terhadap produktifitas peternakan unggas di Indonesia, khussusnya di Jawa Barat. Pembatasan gerak berskala besar menjadi salah satu penyebab yang menyebabkan terhambatnya distribusi pakan, produktifitas unggas menurun, penurunan minat konsumen. Sakah satu kendala yang dihadapi peterna pada skala mikro dan makro adalah manajemen pakan secara langsung di dalam kandang perwatan, yaitu proses pemberian dan penjadwalan pakan dan suplemen. Edukasi program inovasi desain dan pengembangan perangkat pengendali alat pakan ternak dengan teknologi loT dapat menjadi akternatif perbaikan produktifitas peternakan unggas. Proses kerja yang efektif dengan otomatisasi penjadwalan dan pengaturan kuantitas pakan, serta pengguna akan mendapatkan data notifikasi dari aplikasi blynk tentang kondisi ketersediaan pakan dan nutrisi.
\end{abstract}

Kata kunci: alat pakan otomatis; loT; peternakan unggas

\begin{abstract}
The Covid-19 pandemic has a very significant impact on the productivity of poultry farming in Indonesia, especially in West Java. Large-scale movement restriction is one of the causes which causes the distribution of feed to be obstructed, poultry productivity decreases, and consumer interest decreases. One obstacle faced by peterna at the micro and macro scale is direct feed management in the care cage, namely the process of feeding and scheduling feed and supplements. Educational design innovation programs and development of animal feed control devices with loT technology can be an alternative to improve the productivity of poultry farms. Effective work processes by automating the scheduling and setting of feed quantities, and users will get notification data from the Blynk application regarding conditions of feed availability and nutrition.
\end{abstract}

Keywords: automatic feed equipment; lot, poultry farming

\section{PENDAHULUAN}

Kecamatan salah satu kecamatan di Kabupaten Karawang dengan luas wilayah $33,46 \mathrm{~km}^{2}$, dengan wilayah geografis berbatasan dengan Kec. Pedes di bagian utara, Kec. Kabupaten Karawang Barat di selatan, Kec. Rawamerta di bagian timur dan Kec. Batujaya di bagian barat. Kecamatan ini mengalami pemekaran pada tahun 1999 sesuai dengan Perda Kabupaten Karawang Nomor 2 Tahun 2003 menjadi Kec. Kutawaluya dan Kec. Jayakerta, dan terdiri dari 9 Desa, yang salah satunya merupakan Desa Kertasari yang merupakan wilayah kegiatan Pengabdian kepada Masyarakat (PkM) Pemprov Jabar, "Profil Daerah Kabupaten
Karawang," last modified 2017, https://jabarprov.go.id/index.php/pages/id/1055. Desa Kertasari memiliki potensi wilayah yaitu daerah peternakan unggas, dari usaha mikro hingga pengusaha makro. Analisis situasi dilakukan dengan melakukan survey tentang produktifitas usaha peternakan unggas dimasa pandemi Covid-19. Hasil wawancara dari beberapa peternak unggas menyatakan bahwa hasil produksi menurun disebabkan oleh beberapa faktor, seperti terhambatnya proses pengirman pakan dan suplemen unggas, penurunan permintaan konsumen, selain itu karena pembatasan gerak peternak untuk menjaga dari paparan virus covid-19. 
Perkembangan peternakan unggas selain di daerah secara gobal di Indonesia juga mendapatkan pengaruh karena pandemi Covid 19. Rata-rata share yang diterima peternak daging ayam broiler pada tahun 2018 dan 2019 berkisar antara $46,64 \%$ dan $47,89 \%$; selama periode Covid-19 antara Juni-Juli 2020 tersebut pangsa peternak sekitar $49,59 \%$ yang terjadi karena disparitas harga antar daerah menjadi besar; harga pergerakan ekstrim; konsumsi dan produksi menurun tajam; produk impor diblokir; terganggunya sistem rantai pasok; harga turun sementara permintaan juga menurun karena penurunan daya beli Surni et al., "SocioEconomic Impact of the Covid-19 Pandemic: Empirical Study on the Supply of Chicken Meat in Indonesia," <i>AIMS Agriculture and Food</i> 6, no. 1 (2021): 65-81.(Surni et al., 2021)(Surni et al., 2021). Hasil survey yang dilakukan peternak unggas di NTT $(57 \%)$ menyatakan kesulitan dalam mengakses pakan, $43 \%$ responden melaporkan kesulitan menjual ayam karena dilakukan penutupan restoran karena pandemi COVID-19 Prisma AustraliaIndonesia Partnership for Promoting Rural Incomes through Support for Markets in Agriculture, A Qualitative Study on Livestock Farmers Behaviour during the COVID-19 Pandemic in Three PRISMA Target Provinces, 2020, https://aipprisma.or.id/data/public/uploaded_file/2020-0529_09-46-47am_PRISMA_Report_Covid19_Study_-

Farmers_Livestock_Perspective_(English).pd f.. Dampak lain yang terjadi pada usaha peternakan unggas di indonesia adalah adanya gangguan rantai pasokan menyebabkan ketimpangan antara supply dan penurunan demand mencapai $30-40 \%$ dan bobot ayam terjual diatas $1.7 \mathrm{~kg}$, yang terjadi akibat terganggunya distribusi Day Old Chick (DOC), pakan dan obat-obatan serta kegiatan operasional V. Armelia et al., "DAMPAK SOSIAL EKONOMI COVID-19 TERHADAP USAHA PETERNAKAN BROILER DI INDONESIA," in Prosiding Seminar Teknologi Dan Agribisnis Peternakan VII-Webinar: Prospek Peternakan Di Era Normal Baru Pasca Pandemi COVID-19, Fakultas Peternakan Universitas Jenderal Soedirman, ISBN: 978602-52203-2-6, 2020..

Program pengabdian yang menjadi kegiatan Pengabdian kepada Masyarakat (PkM) yaitu sosialisasi desain dan pengembangan alat pakan ternak otomatis. Sehingga sasaran utama dari program pengabdian ini yaitu para peternak yang masih melakukan pemberian pakan secara manual. Pemberian pakan dengan cara manual tersebut kurang efektif dan memakan banyak waktu
(Anwar Kholidi N, 2015). Kemudian biaya pakan merupakan komponen tertinggi dari usaha pemeliharaan ternak $(70 \%)$. Salah satu upaya penekanan biaya pakan adalah dengan mencegah pemborosan pemberian pakan tanpa mengganggu performan ternak dengan cara melakukan pembatasan pakan (Dini Hardini, 2013). Pembatasan pemberian pakan ini masih kontroversial, karena menurut Fisher (1984) dan Reece et al. (1990) menyatakan bahwa pembatasan pemberian pakan sekecil apapun akan menurunkan bobot badan akhir. Akan tetapi, perkembangan terakhir hasil penelitian Fanooci and Torki, (2010) menghasilkan performans broiler yang semakin baik dengan pemberian pakan secara terbatas pada periode yang pendek. Selanjutnya Zulfanita et al. (2011) menyatakan bahwa para peneliti melaporkan ayam broiler yang dibatasi pakannya menunjukkan efisiensi pakan yang lebih baik dan terjadi penurunan kandungan lemak tubuh.

Manajemen pakan unggas pada masa pandemi covid 19 menjadi faktor utama kelangsungan hidup usaha peternakan unggas jenis ayam khususnya di Indonesia. Pakan ayam untuk memenuhi kebutuhan nutrisi yang berasal dari sumber protein, dimana sebagian besar merupakan pakan konvensional seperti bungkil kedelai, tepung ikan, Meat Bone Meal (MBM), Poultry Meat Meal (PMM) yang memiliki harga cukup mahal, sehingga pemberiannya harus tepat untuk menekan biaya pakan yang menduduki biaya tertinggi yaitu kurang lebih $65 \%$ dari biaya produksi N. I. Varianti, U. Atmomarsono, and L. D. Mahfudz, "Pengaruh Pemberian Pakan Dengan Sumber Protein Berbeda Terhadap Efisiensi Penggunaan Protein Ayam Lokal Persilangan," Agripet 17, no. 1 (2017). A. W. Trisnanto, E Suprijatna, and B Sukamto, "Pengaruh Frekuensi Pemberian Pakan Dan Periode Pemberian Pakan Terhadap Kecernaan Ayam Buras Super," Jurnal Sain Peternakan Indonesia 13, no. 2 (2018),

https://ejournal.unib.ac.id/index.php/jspi/index.. Pengurangan biaya pakan menyebabkan peningkatan efisiensi produksi dan profitabilitas perusahaan unggas. Strategi penekanan biaya pakan dapat dikurangi melalui metode pengaturan waktu pemberian pakan; manipulasi bahan pakan; penggunaan asam amino sintetis; suplemen enzim; penggunaan perasa; penutup bulu S. C. Vetrivel and $M$. Mohanasundari, "Importance of Creativity and Innovation in Poultry Farming," International Journal of Innovative Research in Management Studies (IJIRMS) ISSN (Online): 2455-7188 1, no. 5 (2016).. Pembatasan waktu pemberian makan adalah praktik alternatif pembatasan 
pakan dengan intensitas rendah dan dapat mengurangi stress, yang ditunjukkan dalam proses pemeliharaan karkas usia 21 hari, nilai asupan pakan dan rasio konversi pakan dalam perlakuan pembatasan waktu makan secara signifikan lebih rendah dibandingkan dengan kondisi ayam pedaging diberi makan ad libitum A. Azis, S Berliana, and Afriani, "Research Article Effects of Feeding Time Restriction During the Whole Rearing Period on the Growth Performance of Broiler Chickens," International Journal of Poultry Science ISSN 1682-8356 18, no. 1 (2019).. Pemberian pakan secara efektif dapat mempertimbangkan suhu lingkungan khususnya pada kandang terbuka. Di daerah tropis dengan suhu lingkungan yang tinggi sangat berpengaruh bagi perkembangan unggas, dimana unggas hanya dapat mengatur suhu tubuhnya dalam kisaran lingkungan antara $16-26^{\circ} \mathrm{C}$ atau dalam kondisi heat stress. Pengaturan pemberian pakan selama periode terpanas dan pemberian makan selama periode pendinginan (pagi atau sore hari) terbukti memiliki efek perbaikan yaitu tidak mengurangi bobot dan kualitas telur S. S. Diarra and P. Tabuacir, "Feeding Management of Poultry in High Environmental Temperatures," International Journal of Poultry Science ISSN 1682-8356 13, no. 11 (2014).. Suhu udara di Indonesia yang sangat fluktuatif yaitu titik terendah pada jam 05.00-06.00 pagi sebesar $19^{\circ} \mathrm{C}$ dan mencapai puncak pada jam 12.0013.00 sebesar $32,2^{\circ} \mathrm{C}$, pergerakan suhu ini menjadi dasar perkiraan suhu nyaman pada ayam yaitu pagi hari yang dapat menjadi alternatif untuk waktu pemberian pakan. Pemberian pakan dalam satu hari harus diatur untuk diberikan lebih dari 2 kali sehari, karena dapat menghemat pakan, mengurangi resiko kandang kotor, menambah nafsu makan dan ayam tidak malas untuk minum. Waktu pemberian pakan selama 8 jam setiap hari dapat meningkatkan bobot badan akhir dan konversi ransum lebih rendah Trisnanto, Suprijatna, and Sukamto, "Pengaruh Frekuensi Pemberian Pakan Dan Periode Pemberian Pakan Terhadap Kecernaan Ayam Buras Super."

Proses pemberian pakan yang manual untuk proses produksi yang besar, menjadi permasalahan mitra untuk mengatur efektifitas pakan. Inovasi teknologi dibutuhkan khususnya untuk mengatasi variabel pemberian pakan yaitu usia ternak dan waktu pemberian pakan. Usia ternak berpengaruh pada kuantitas pakan yang diberikan. Kendala ini didukung juga dengan kondisi pandemi Covid 19 yang melanda dunia dan berdampak khususnya pada peternak unggas. Solusi memberikan edukasi tentang inovasi desain dan pengembangan perangkat pengendali alat pakan ternak otomatis menggunakan teknologi Internet of Things.

\section{METODE}

Tahapan dalam melaksanakan kegiatan PkM sebagai berikut.

\section{Analisis dan identifikasi wilayah}

Identifikasi wilayah dilakukan dengan memfokuskan sasarn pelaksanaan kegiatan PkM pada usaha mikro, menengah atau makro pada sektor peternakan unggas. Sehingga dari hasil survey diperoleh beberapa mitra yang dapat memberikan informasi tentang kondisi produksi peternakan di masa pandemi Covid-19. Mitra pertama adalah PD. Alam Jaya Kusuma merupakan salah satu usaha yang bergerak dibidang agribisnis yaitu peternakan ayam, khususnya sebagai distributor unggas jenis perent. Mitra kedua adalah PT. Tri Satya Mandiri (TSM) yang merupakan perusahan gabungan dari empat unit usaha bisnis yang bergerak dibidang peternakan ayam pedaging (Broiler) dengan kapasitas kandang 14 kandang dengan luas 7,5 m x $63 \mathrm{~m}$ dengan populasi ayam sebanyak 7000 ekor dan kandang dengan luas $7,5 \mathrm{~m} \times 45,5 \mathrm{~m}$ dengan populasi ayam sebanyak 5000 ekor. Mitra tersebut cukup mewakili informasi tentang kondisi produktifitas peternakan unggas di karawang, sehingga dapat menjadi media diskusi dan pengembangan inovasi berikutnya.

\section{Sosialisasi Program}

Sosialisasi program kegiatan dilakukan dalam beberapa tahap yaitu 1) melakukan survey dan pendataan kepada mitra peternak unggas mikro hingga makro; 2) Diskusi terkait kondisi produktifitas peternakan unggas dan kondisi lapangan produksi unggas dalam kandang terbuka dan semi terbuka; 3) Sosialisasi program inovasi desain dan pengembangan perangkat pengendali alat pakan ternak otomatis menggunakan teknologi Internet of Things (IOT) sebagai alternatif untuk melakukan manajemen pakan dan suplemen pada masa pandemi Covid-19 dan dapat dikembangkan untuk menjaga produktifitas kinerja peternak kedepannya.

\section{Workshop Program Inovasi}

Kegiatan workshop dan pendampingan dilakukan dengan Metode penyuluhan secara langsung dengan mendatangi peternak dan secara daring melalui aplikasi online meeting untuk membahas lebih detail tentang produk inovasi yang ditawarkan sebagai solusi manajemen pakan secara otomatis.

HASIL DAN PEMBAHASAN 
Hasil dan pembahasan menunjukkan proses kegiatan yang dilakukan selama proses pelaksanaan PkM sesuai dengan metode pelaksanaan.

\section{Kegiatan Survei Dan Pendataan Mitra PkM}

Persiapan pelaksanaan PKMS dilakukan dengan identifikasi wilayah yaitu dengan survey lokasi dan menghubungi mitra yang diawali dengan pengajuan perijinan kegiatan PkM sebagai pelaksanaan Tri Dharma dan menggali informasi tentang kondisi usaha peternakan unggas di wilayah. kepada Kepala Desa Kertasari, Kecamatan Rengasdengklok yang ditunjukkan pada Gambar 1. Hasil wawancara menunjukkan antusiasme pihak desa yaitu Kepala Desa dengan program yang akan dilaksanakan, khususnya dapat menjadi edukasi bagi peternak lokal berskala mikro.

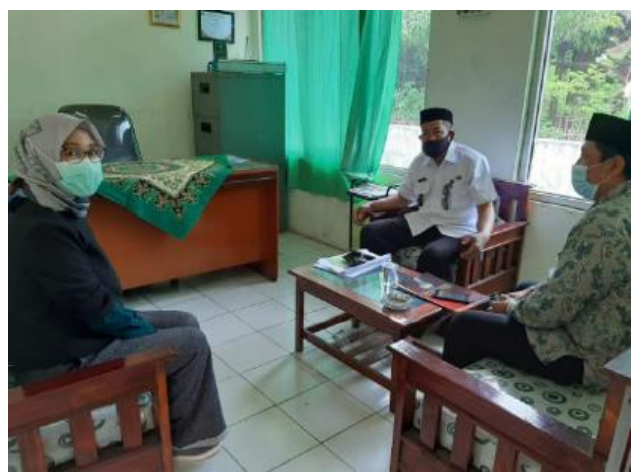

Gambar 1. Kegiatan perijinan dan diskusi kepada Kepala Desa tetang potensi pengusaha unggas di Desa Kertasari

Kegiatan berikutnya adalah survey dan pendalaman mitra dengan melakukan wawancara untuk mengetahui kondisi kandang peternakan unggas, seperti ditunjukkan pada Gambar 2 merupakan kandang modern dengan kapasitas yang diterntukan dari perbandingan luas wilayah dan kepadatan DOC (Day Old Chick)

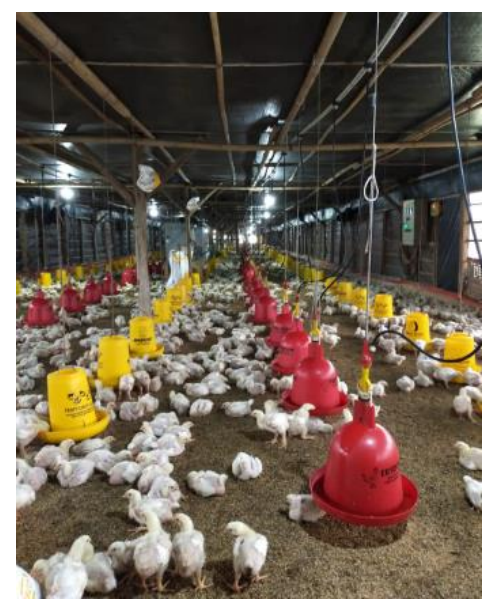

Gambar 2. Kondisi kandang modern

\section{Diskusi terkait kondisi produktifitas peternakan unggas}

Kegiatan diskusi terkait kondisi produktifitas peternakan unggas sangat penting khususnya untuk dapat menggali permasalahan tentang kebutuhan peternak, sehingga dapat memberikan alternatif solusi khususnya untuk meningkatkan produksi unggas pada faktor internal/ manajemen pakan internal oleh peternak di masa pandemi Covid-19 yan ditunjukkan pada Gambar 3.

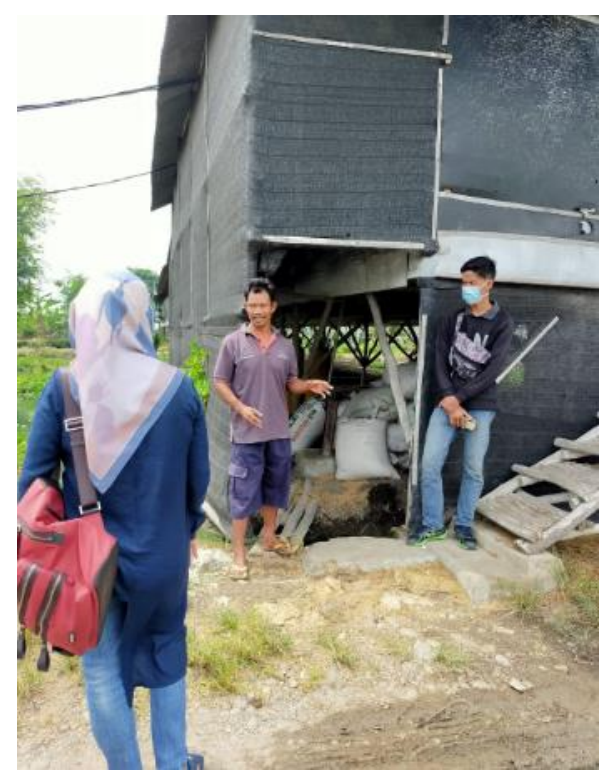

(a)

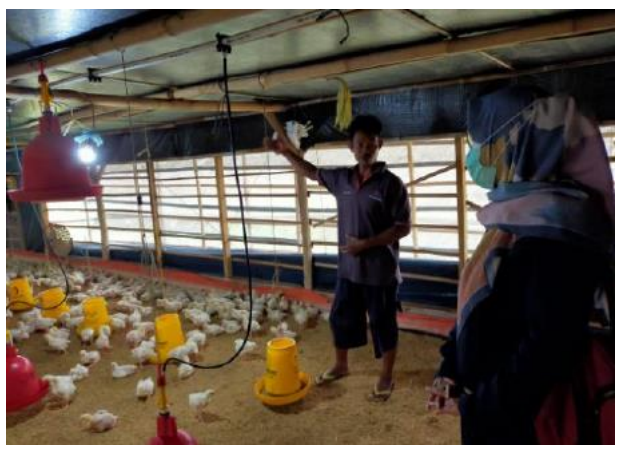

(b)

Gambar 3. (a)(b) Kegitan Diskusi dengan Peternak

Kegiatan pada Gambar 3 dilakukan secara langsung pada peternak unggas dan dapat mengetahui kondisi lapangan tentang permasalahan pada kandang peternak.

\section{Workshop Program Inovasi}

Kegiatan workshop dilakukan kepada perwakilan peternak, perwakilan aparat desa dan perwakilan akademisi yaitu dosen dan mahasiswa. Kegiatan berjalan efektif ditengah kondisi pandemi Covid-19 dengan melakukan kegiatan workshop online melalui zoom meet tentang edukasi program inovasi desain dan 
pengembangan perangkat pengendali alat pakan ternak otomatis menggunakan teknologi Internet of Things. Para peserta akan mendapatkan gambaran detail tentang desain mekanik dan elektrik tentang alat inovasi seperti ditunjukkan pada gambar 4.

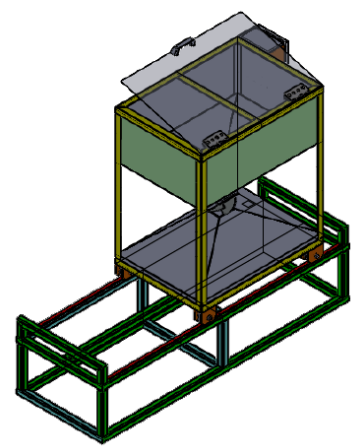

Gambar 4. Desain alat pakan ternak otomatis menggunakan teknologi Internet of Things.

Gambar 4 merupakan desain alat pakan dan suplemen ternak secara otomatis dengan pemantau jarak jauh dengan mengimplementasikan teknologi Internet of Things, dengan dimensi menyesuaikan dengan kebutuhan. Inovasi alat pakan ternak otomatis menggunakan teknologi Internet of Things ditunjukkan pada Gambar 5.

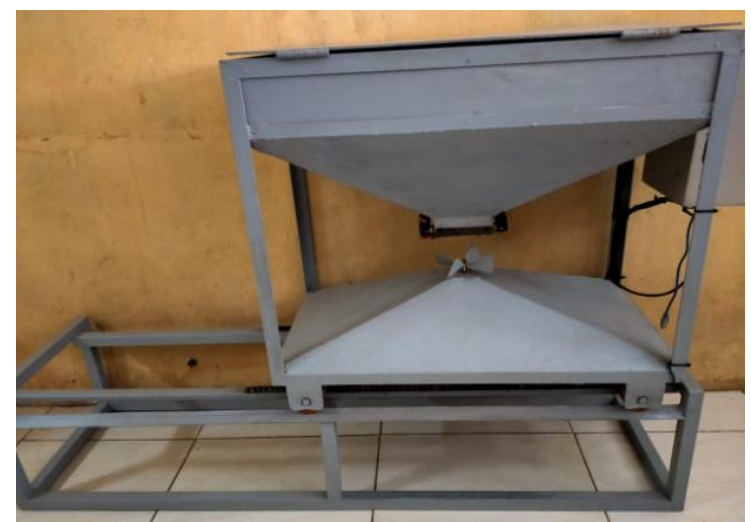

Gambar 5. Alat pakan dan suplemen ternak otomatis

Gambar 5 menunjukkan alat pakan ternak otomatis yang terbuat dari material SPHC $2 \mathrm{~mm}$ dengan kapasitas beban pakan dan suplemen 10 kilogram. Alat tersebut bekerja sesuai dengan penjadwalan jam 08.00 dan 16.00 merupakan proses pemberian pakan dan jam 19.00 proses pemberian suplemen yang dikontrol secara otomatis. Teknologi loT merupakan teknologi pemantau berbasis internet, yang akan mengirimkan sinyal notifikasi kondisi pakan dan suplemen melalui aplikasi Blynk pada smart phone pengguna.
Kegiatan sosialisasi dilakukan secara daring dengan menggunakan aplikasi meeting online dengan memberikan paparan dengan menggunakan materi pada power point yang disampaikan secara daring seperti ditunjukkan pada Gambar 6.

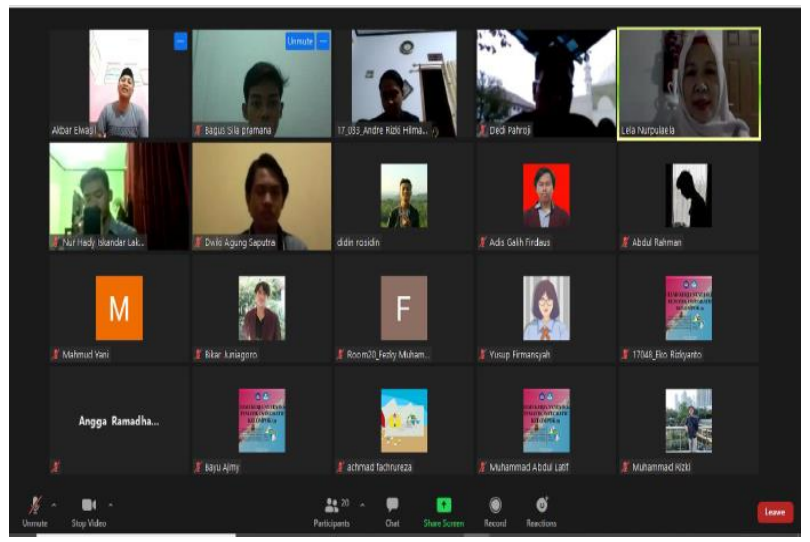

Gambar 6. Kegiatan sosialisasi secara online

Kegiatan berikutnya adalah pendampingan pribadi dengan melakukan sosialisasi secara langsung pada perwakilan peternak untuk menunjukkan fungsi dan prinsip kerja alat pakan dan suplemen otomatis, seperti ditunjukkan pada gambar 7 .

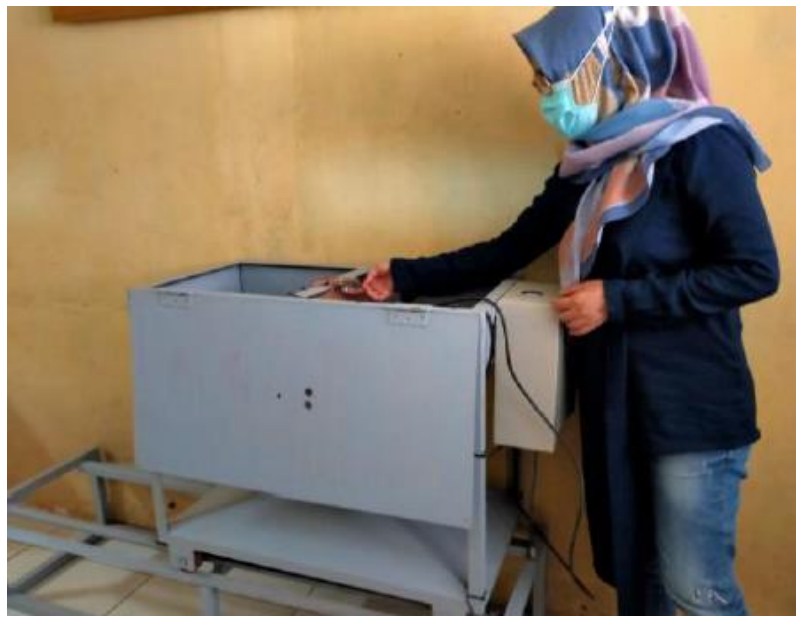

Gambar 7. Sosialisasi secara lanngsung pada perwakilan peternak

Kegiatan ini akan memberikan gambaran sacara jelas tentang alat pakan dan suplemen unggas. Kegiatan ini hanya dilakukan pada beberapa peternak karena kondisi pandemi yang tidak memungkinkan dilakukan secara bersamaan.

\section{SIMPULAN DAN SARAN}

Berdasarkan hasil kegiatan pengabdian ini dapat ditarik simpulan : 1). Mitra mendapatkan edukasi tentang solusi manajemen pakan dan suplemen ternak unggas pada masa pandemi Covid-19 dengan mengimplementasikan alat pakan otomatis dengan teknologi Internet of 
Things, 2). Mitra dapat mengembangkan ide inovasi manajemen pakan dengan mengembangkan lebih lanjut setelah pandemi Covid-19 berakhir dan 3). Mitra dapat melakukan produksi secara pribadi inovasi alat pakan otomatis dengan teknologi Internet of Things seuai dengan kapasitas kandang ternak

\section{UCAPAN TERIMAKASIH}

Ucapan terima kasih disampaikan kepada Universitas Singaperbangsa Karawang melalui Hibah Penelitian dan Pengabdian kepada Masyarakat dengan Skema Penelitian Strategis.

\section{DAFTAR RUJUKAN}

Armelia, V., N. D. Arkan, Ismoyowati, and N. A. Setianto. "Dampak Sosial Ekonomi Covid19 Terhadap Usaha Peternakan Broiler Di Indonesia." In Prosiding Seminar Teknologi Dan Agribisnis Peternakan VIIWebinar: Prospek Peternakan Di Era Normal Baru Pasca Pandemi COVID-19, Fakultas Peternakan Universitas Jenderal Soedirman, ISBN: 978-602-52203-2-6, 2020.

Azis, A., S Berliana, and Afriani. "Research Article Effects of Feeding Time Restriction During the Whole Rearing Period on the Growth Performance of Broiler Chickens." International Journal of Poultry Science ISSN 1682-8356 18, no. 1 (2019).

Diarra, S. S., and P. Tabuacir. "Feeding Management of Poultry in High Environmental Temperatures." International Journal of Poultry Science ISSN 1682-8356 13, no. 11 (2014).

Pemprov Jabar. "Profil Daerah Kabupaten Karawang." Last modified 2017. https://jabarprov.go.id/index.php/pages/id 11055 .

Prisma Australia-Indonesia Partnership for Promoting Rural Incomes through Support for Markets in Agriculture. A Qualitative Study on Livestock Farmers Behaviour during the COVID-19 Pandemic in Three PRISMA Target Provinces, 2020. https://aip-

prisma.or.id/data/public/uploaded_file/20

20-05-29_09-46-

47am_PRISMA_Report_Covid-

19_Study_-

_Farmers_Livestock_Perspective_(Englis h).pdf.

Surni, D. R. Nendissa, M. A. Wahib, M. H. Astuti, P. Arimbawa, Miar, M. M. J Kapa, and E. F. Elbaar. "Socio-Economic Impact of the Covid-19 Pandemic: Empirical Study on the Supply of Chicken Meat in Indonesia." AIMS Agriculture and Food 6, no. 1
(2021): 65-81.

Trisnanto, A. W., E Suprijatna, and B Sukamto. "Pengaruh Frekuensi Pemberian Pakan Dan Periode Pemberian Pakan Terhadap Kecernaan Ayam Buras Super." Jurnal Sain Peternakan Indonesia 13, no. 2 (2018).

https://ejournal.unib.ac.id/index.php/jspi/i ndex.

Varianti, N. I., U. Atmomarsono, and L. D. Mahfudz. "Pengaruh Pemberian Pakan Dengan Sumber Protein Berbeda Terhadap Efisiensi Penggunaan Protein Ayam Lokal Persilangan." Agripet 17, no. 1 (2017).

Vetrivel, S. C., and M. Mohanasundari. "Importance of Creativity and Innovation in Poultry Farming." International Journal of Innovative Research in Management Studies (IJIRMS) ISSN (Online): 245571881 , no. 5 (2016). 